\title{
Update on the herpetofauna of the Dodecanese Archipelago (Greece)
}

\author{
Augusto Cattaneo', Cristina Cattaneo ${ }^{2} \&$ Mauro Grano ${ }^{3}$ \\ 'Via Cola di Rienzo 162, 00195 Rome, Italy \\ ${ }^{2}$ Via Eleonora d'Arborea 12, 00162 Rome, Italy \\ ${ }^{3}$ Sezione Lazio of Societas Herpetologica Italica, Via Valcenischia 24, 00141 Rome, Italy \\ *Corresponding author, e-mail: elaphe58@yahoo.it
}

\begin{abstract}
In this paper, an update on the Dodecanese (Greece) herpetofauna is provided. In this Archipelago, 8 Amphibians (2 Salamandrididae,1 Pelobatidae, 2 Bufonidae, 1 Hylidae, 2 Ranidae) and 31 Reptiles (1 Testudinidae, 1 Emydidae, 1 Geoemydidae, 1 Trionychidae, 1 Cheloniidae, 1 Agamidae, 2 Gekkonidae, 4 Lacertidae, 4 Scincidae, 1 Anguidae, 1 Blanidae, 1 Typhlopidae, 1 Boidae, 10 Colubridae, 1 Viperidae) occur. Notes relating to animals' ecology and to critical habitats are also given.
\end{abstract}

KEY WORDS Dodecanese; Greece; amphibians; reptiles; conservation; herpetofauna.

Received 07.12.2019; accepted 20.02.2020; published online 16.03.2020

\section{INTRODUCTION}

Rhodes and all of the islands that make up the Dodecanese Archipelago (Greece) are very important from an environmental and naturalistic point of view. The vertebrate fauna, and in particular the herpetofauna, is particularly interesting and rich. Most of the species are of Anatolian origin because several million years ago these islands where connected with Asia Minor. Recent evidence from the investigation of genetic variation in amphibians and reptiles shows the potential role of the Anatolia region as a major refugium and a source of re-expansion for several amphibian and reptile taxa during the Pliocene and Pleistocene. Unfortunately, a strong anthropic impact, including new forms of agriculture, pollution and global warming, has modified many natural habitats and has led to the rarefaction of some of the herpetofauna species. Numerous studies carried out in the last twenty years have increased the knowledge of the species present on Rhodes and on the Dodecanese Islands. Currently, six species of tortoises and terrapins, fourteen species of saurians, thirteen species of snakes and eight species of amphibians are known to inhabit these islands. It is worth noting that Rhodes Island lacks venomous snakes.

\section{MATERIAL AND METHODS}

This work is intended to be an update of the data relating to the herpetofauna of the Dodecanese. The data have been extrapolated mainly from Augusto Cattaneo, which carried out extensive herpetological research in the Aegean islands from 80 s of the last century to date, from Mauro Grano and Cristina Cattaneo that began their scientific research in the Aegean area in 2010 and from the international bibliography concerning the study area. The most recent taxonomy was taken into account. 


\section{RESULTS AND CONCLUSIONS}

\section{Amphibians in the Dodecanese Islands}

In the Dodecanese, only eight amphibian species have been found, mainly due to the increasingly dry climate that characterizes this Archipelago. There are, however, two species of salamander, which is particularly interesting given the close dependence that these salamanders also have on aquatic environments. The Karpathos salamander Lyciasalamandra helverseni (Pieper, 1963)

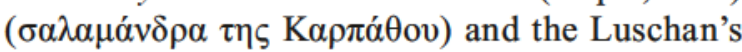
salamander Lyciasalamandra luschani (Stein-

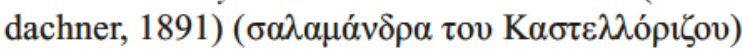
have recently been recognized as two distinct species (Veith \& Steinfartz, 2004). The Karpathos salamander has a maximum length of $14 \mathrm{~cm}$, and the females are bigger than the males. It feeds on invertebrates and seeks cooler temperatures and humid conditions, as noted previously. This species occurs on Karpathos, Kasos and Saria (Lymberakis et al., 2009). The Luschan's salamander has the same dimensions and ecological characteristics, but lives only on Kastellorizo where it is represented by the subsp. basoglui (Baran \& Atatör, 1980).

There is record of the Syrian spade-foot, Pelo-

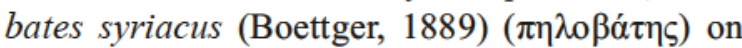
Kos (Dimaki, 2002; Cattaneo, 2005a); Džukic et al., 2008). It is mainly a fossorial species, and the terrestrial habitats in which it lives are generally open, uncultivated lands such as light forests, steppe, semi-desert and rocky areas. It is generally less selective than Pelobates fuscus in terms of soil choice, inhabiting not only the soft soils preferred for fossorial life, but also solid, rocky soils and friable clay with pebbles. Spawning sites include: stagnant temporary waterbodies, river or lakeside temporary waterbodies and large permanent pools, but it can also be found in slightly modified environments, such as intensively grazed areas (Agasyan et al., 2009).

The common toad Bufo bufo (Linnaeus, 1758) $(\chi \omega \mu \alpha \tau o ́ \varphi \rho v v o \varsigma)$ has been reported on Kos (Cattaneo, 2005a) (Fig. 1). The common toad is more active in wet seasons and is most commonly found in areas close to the water such as woodlands, forests, marshes and meadows. The common toad is also a nocturnal animal, spending the daylight hours hidden and hunting by night.
Another toad species, the green toad Bufotes

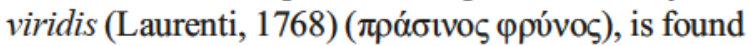
on Rhodes, Leros, Lipsi (Broggi, 2008), Kalymnos, Kastellorizo, Kos, Symi and Tilos. This species is dependent on water for reproduction, like most amphibians, but it can also be found in dry habitats and away from water sources. The main threat to its survival appears to be the loss of breeding habitats through wetland drainage, desiccation and aquatic pollution. Local populations may also be declining due to mortality on roads, which often occurs when they are on the move during their reproductive periods (Cattaneo, 2005a, b).

One of the frogs with the most impressively distinctive appearance is the eastern tree frog, Hyla orientalis Bedriaga, $1890 \quad$ ( $\alpha v \alpha \tau 0 \lambda$ ıкó $\varsigma$ $\delta \varepsilon v \delta \rho o \beta \alpha ́ t \rho \alpha \chi 0 \varsigma)$ which can reach a length of five $\mathrm{cm}$, but is usually shorter, and the females are bigger than the males. Given that $H$. orientalis is mainly nocturnal, and found in reed-beds, bushes and other dense vegetation, it is not easy to spot. Rhodes and Kos are the only islands of the Dodecanese where this species is found. On Kos Island, the largest population is found in the salt lake of Alikes (Cattaneo, 2005a).

The Bedriaga's frog, Pelophylax bedriagae

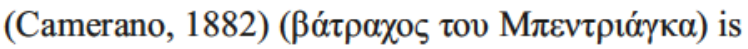
found on Kos, Astypalea and Rhodes. In the past, this frog has also been reported on Tilos (Papatheodorou \& Pagkas, 2001) but this is not the case in recent times (Broggi, 2006; Cattaneo, 2009; Grano et al., 2018). The total length can reach up to $15 \mathrm{~cm}$, though it is usually shorter. A largely aquatic species, it makes its home in permanent wetlands with rich aquatic vegetation such as: ponds, rain pools, streams, rivers, irrigation channels, reservoirs, marshes, springs and fishponds, though it is sometimes also found in the surrounding terrestrial habitats and can occur in modified habitats where suitable wetlands exist.

The Karpathos frog Pelophylax cerigensis (Beerli, Hotz, Tunner, Heppich et Uzzell, 1994)

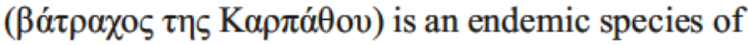
Karpathos (Fig. 2). It mates in spring and females lay their eggs in clusters of a few hundred. It is a single island-endemic and it is considered the most endangered anuran amphibian in Europe because its range is restricted to Karpathos island, where it occurs with two populations only in two streams: Nati and Argoni (Temple \& Cox, 2009; Pafilis et 
al., 2019). Both these streams have a much reduced water flow and, especially in the summer period, they decrease into small pools that are sometimes very spaced-out from each other. In addition, the global warming and the low rainfall, contribute negatively to the survival of this species. Due to these reasons, it currently faces a high risk of extinction and is classified as "Critically Endangered" on the red list of IUCN. The Pelophylax populations occurring on Rhodes, that were previously assigned to this species, are now allocated to $P$. bedriagae (Lymberakis et al., 2007). Recent studies (Toli et al., 2018) have suggested that specimens from Karpathos and Rhodes constitute a single clade, indicating the occurrence of $P$. cerigensis on Karpathos and Rhodes, which contrasts previous studies, and suggests that further research is needed.

\section{Tortoises and Terrapins}

In the Dodecanese the only tortoise species that has been recorded so far is Testudo graeca, Linnaeus, 1758 ( $\varepsilon \lambda \lambda \eta v \eta \kappa \eta ́ ~ \chi \varepsilon \lambda \omega ́ v \alpha)$ (Fig. 3). It is found on Leros, Symi, Kalymnos and Kos with the subspecies ibera Pallas, 1814. In addition, a deceased juvenile specimen of T. graeca was found on Seskli Islet (south of Symi) in August 2017 by two of the authors of this contribution, M. Grano and C. Cattaneo. Although the species' presence on the islet is very plausible given the proximity to Symi, further confirmation is needed. On Rhodes, south of Lin-

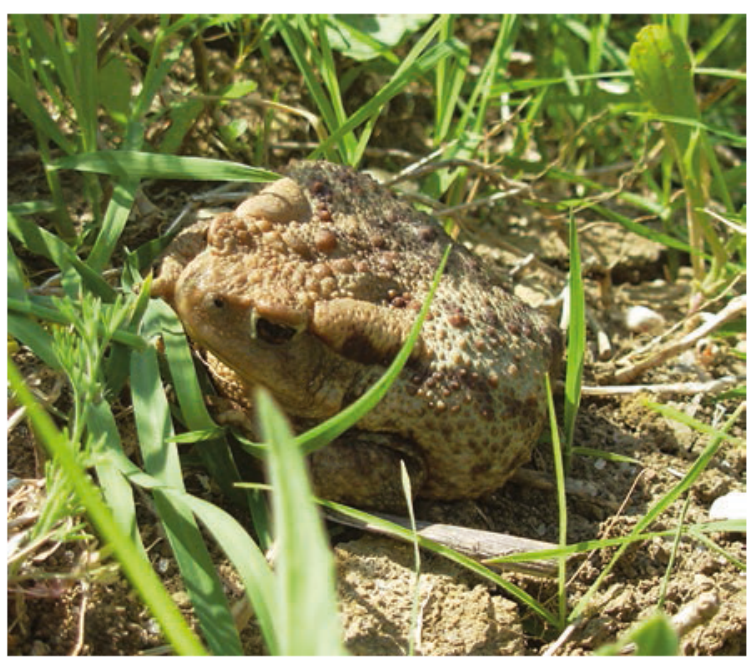

Figure 1. Bufo bufo (Kos island). dos, in April 2005, a single juvenile male specimen of Testudo hermanni, belonging to the subsp. boettgeri Mojsisovics, 1889, was found (Bader et al., 2009). Most likely, the animal escaped or was released from captivity since there were newly built houses in the vicinity. The natural occurrence of

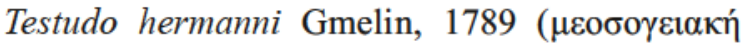
$\chi \varepsilon \lambda \omega v \alpha$ ) on the Aegean Islands would be less likely due to ecological factors: T. graeca chooses drier and more open environments (distinctive features of the Aegean Islands) while T. hermanni lives in wetter, grassy habitats. The ecological differentiation remains even where the two species live in syntopy, as happens on the mainland. It is worth noting that $T$. graeca is always parasitized by ticks (Hyalomma aegyptium) while this is not the case for T. hermanni (Cattaneo, 2008).

With regards to the terrapin species in the Dodecanese Archipelago, Emys orbicularis (Lin-

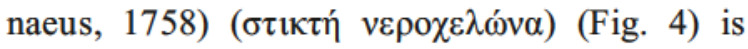
reported only on Kos (Broggi \& Grillitsch, 2012). The caspian terrapin Mauremys rivulata (Valenciennes, 1883) ( $\gamma \rho \alpha \mu \mu \omega \tau$ ๆ́ $v \varepsilon \rho \propto \chi \varepsilon \lambda \omega ́ v \alpha)$ is reported on Rhodes, Symi, Tilos and Kos (Broggi, 2012). Only one specimen of $M$. rivulata has been found on Chalki, so its presence on the island requires further investigation (Grano \& Cattaneo, 2017). It lives in the lower courses of streams and especially in their estuaries. Populations are currently in decline due to the loss or modification of wetland habitats resulting from land use, tourism and inten-

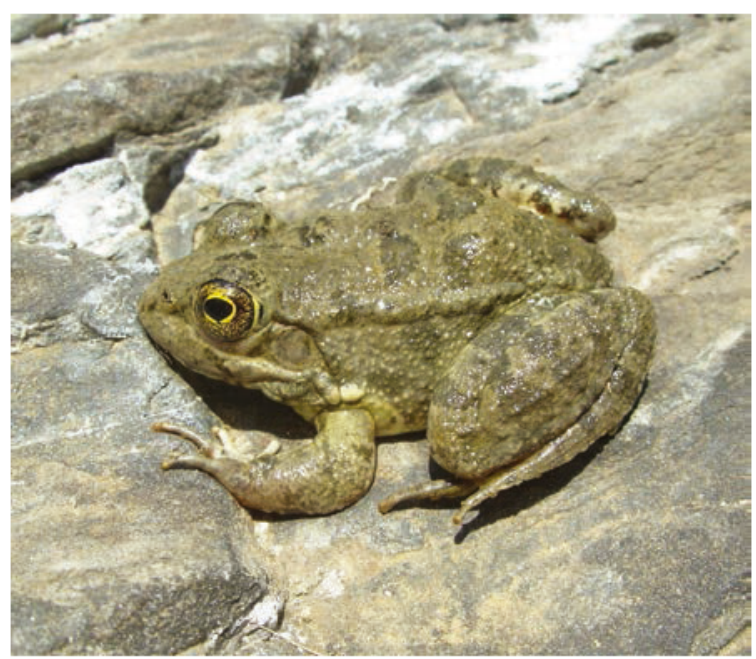

Figure 2. Pelophylax cerigensis (Karpathos island). 
sive agriculture. It is worth noting that some specimens of Trionyx triunguis (Forskål, 1775), a terrapin species that is found in Africa and West Asia, have been detected in the open sea surrounding Rhodes, Leros, Kalymnos and Kos (Taşkavak et al., 1999; Corsini-Foca \& Masseti, 2008).

As for marine turtles, Caretta caretta (Linnaeus, 1758) ( $\chi \varepsilon \lambda \omega v \alpha \alpha \alpha \rho \varepsilon ́ \tau \tau \alpha)$ and Chelonia mydas (Lin-

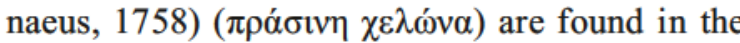
Aegean Sea with reports also coming from the Dodecanese Archipelago.

\section{Lizards}

In the Dodecanese Archipelago thirteen lizard species have been reported.

Within the family Agamidae, quite common on several islands, we have the rough-tailed rock agama, Stellagama stellio (Linnaeus, 1758)

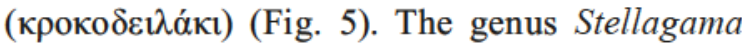
Baig, Wagner, Ananjeva et Böhme, 2012 has seven recognized subspecies and two subspecies can be found specifically in Greece: S. stellio stellio (Linnaeus, 1758) and S. stellio daani (Beutler \& Frör, 1980). In the Dodecanese Archipelago, we find $S$. stellio daani, a diurnal lizard that is always found in rocky habitats and in a variety of Mediterranean, arid and semi-arid environments. It can be found on rocks, trees, and stone walls, and has been reported on Leros, Kalymnos, Telendos, Kos, Patmos, Agathonisi, Nisyros, Tilos, Symi, Seskli,

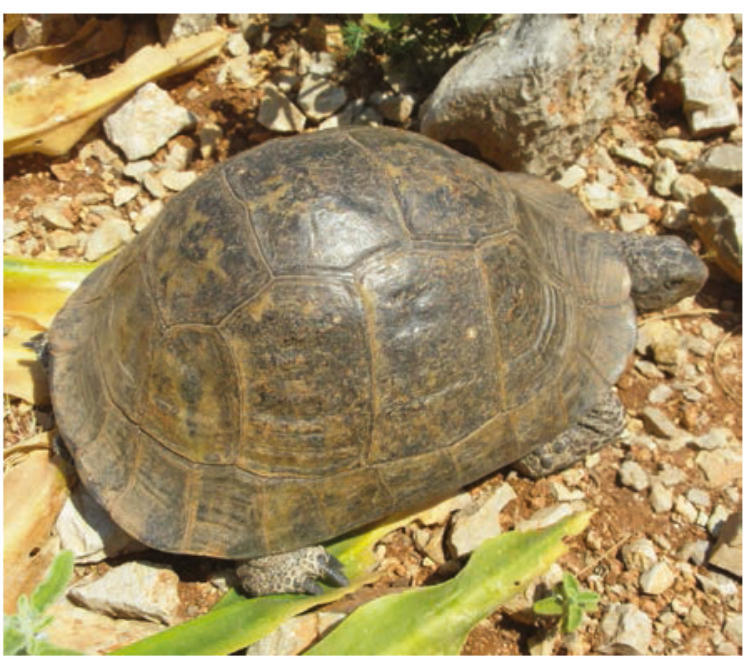

Figure 3. Testudo graeca (Symi island).
Chalki, Alimia (Grano et al., 2015), Karpathos (Grano \& Cattaneo, 2019b) Rhodes and Kastellorizo.

With regards to the family Gekkonidae two gecko species are found in the Dodecanese Archipelago: Hemidactylus turcicus (Linnaeus, 1758) ( $\sigma \alpha \mu \alpha \mu i ́ \delta \imath)$ and Mediodactylus oertzeni (Boettger,

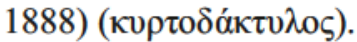

Hemidactylus turcicus (Linnaeus, 1758) (Fig. 6 ), the Turkish gecko, is a nocturnal reptile that generally looks for wet environments. It lives in a great variety of stony habitats, such as: building walls, the stone walls found in fields, under stones and inside cisterns. It has been reported on Astypalea, Patmos, Leros, Lipsi, Arki, Agathonisi, Kalymnos, Nisyros (Cattaneo, 2006), Symi, Tilos, Chalki, Alimia, Rhodes, Karpathos, Kasos and Kastellorizo.

Mediodactylus oertzeni (Boettger, 1888) belongs to the M. kotschyi complex. Mediodactylus kotschyi (Steindachner, 1870) is a small gecko native to southeastern Europe and the Levant, which displays great morphological variation with a large number of recognized subspecies. Through genetic and phylogenetic studies, five new species have been identified within the $M$. kotschyi complex: M. kotschyi (Steindachner, 1870) (mainland, Balkans, most of Aegean islands, and Italy), $M$. orientalis (Štěpánek, 1937) (Levant, Cyprus, STurkey, and SE-Aegean Islands), $M$. danilewskii (Strauch, 1887) (Black Sea region and SW-

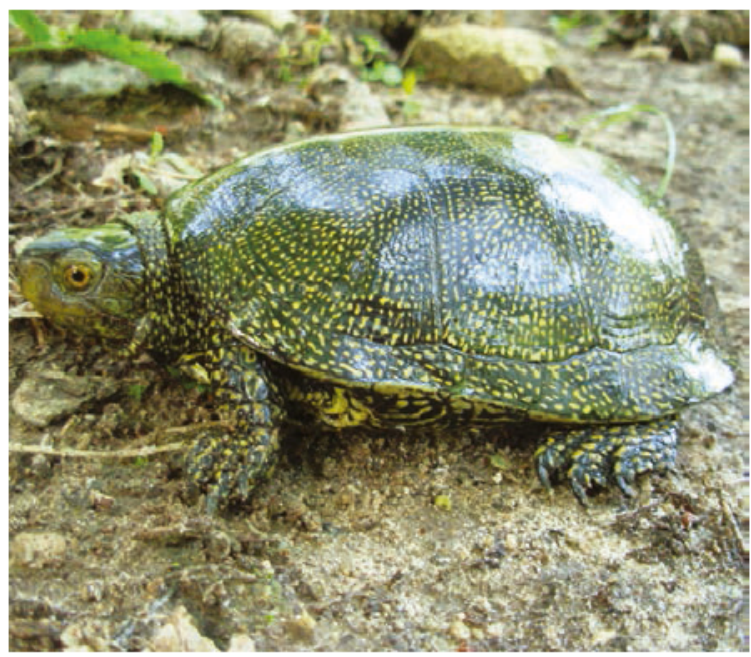

Figure 4. Emys orbicularis (Kos island). 
Turkey), M. bartoni (Štěpánek, 1934) (Crete), and M. oertzeni (Boettger, 1888) (Kasos and southern Dodecanese Islands). Mediodactylus oertzeni (Boettger, 1888) (raised to the rank of species following the genetic and phylogenetic studies) is found in the Dodecanese Archipelago and specifically on Astypalea, with the two islets Kounoupi and Koutsomyti (pers. obs.), Kalymnos, Symi, Karpathos, Kasos, Saria, Chalki. Instead on Kastellorizo occurs $M$. danilewskii. On Megali Sofrano (south of Astypalea) the subspecies $M$. oertzeni stepaneki (Wettstein, 1937) is present. Only on Kos Island can Mediodactylus kotschyi kotschyi (Steindachner, 1870) (Kotsakiozi et al, 2018) be found and on Agathonisi, we find M. orientalis (Stepánek, 1937). Mediodactylus oertzeni, unlike Hemidactylus turcicus, is more diurnal and less anthropophilic. Seeking dry habitats, it is primarily found in arid, stony environments with phryganic vegetation, such as among stones and on stone walls.

Regarding the family Lacertidae in the Dodecanese Archipelago, we find Anatololacerta pelasgiana (Mertens, 1959), Lacerta trilineata Bedriaga, 1886, Ophisops elegans Ménétries, 1832 and Podarcis erhardii (Bedriaga, 1876).

Based on recent studies in the Mediterranean basin (Bellati et al., 2015) there are four recognisable species of Anatololacerta Arnold, Arribas et Carranza, 2007: A. anatolica (Werner, 1900) (WTurkey, up to the north of the Büyük Menderes River, Samos); A. pelasgiana (Mertens, 1959) (SWTurkey from south of the Büyük Menderes River, Ikaria and some islands of the Dodecanese Archipelago); A. budaki (Eiselt \& Schmidtler, 1986) (SW-Turkey from Kaş to Antalya); and A. danfordii (Günther, 1876), (southeasternmost Turkey, province of Mersin).

Anatololacerta pelasgiana (Mertens, 1959) $(\pi \varepsilon \lambda \alpha \sigma \gamma ı \kappa \eta ́ ~ \sigma \alpha v ́ \rho \alpha)$ (Fig. 7) is found in rocky habitats, cultivated areas, and orchards, but also inside villages and towns. In the Dodecanese, it can be found on Nisyros (Cattaneo, 2006), Tilos (Broggi, 2006), Symi and Seskli (subsp. quandttaylori Börner, 1974), Alimia, Rhodes, Strongili (NW of Rhodes), on the nearby Pentanisos Islet (subsp. pentanisiensis Wettstein, 1964), on Kasos (Kornilios \& Thanou, 2016) and on Kastellorizo (Kalaentzis et al., 2018b). Instead on Psomi islet occurs $A$. budaki.
The three-lined lizard, Lacerta trilineata Bedriaga, 1886 ( $\tau \rho \alpha v o ́ \sigma \alpha v \rho \alpha)$ is the largest Lacertide in Greece. It is found throughout the mainland as well as on many islands. It inhabits environments with lower elevations and fairly good vegetation. The $L$. trilineata group comprises three species: L. media Lantz \& Cyrén, 1920 (from central Turkey and eastwards), Lacerta pamphylica Schmidtler, 1975 (central south coast of turkey) and $L$. trilineata Bedriaga, 1886 (Greek mainland and islands). Whereas L. media is a morphologically and genetically distinct taxon, the taxonomic situation for the trilineata + pamphylica clade has historically been problematic. A recent study proposed formal changes to the taxonomy of the L. trilineata pamphylica group to properly reflect the phylogenetic relationships (Kornilios et al., 2019). In Greece the following recognisable taxa occur: L. trilineata trilineata Bedriaga, 1886 (North Macedonia, Peloponnesos, east of Pindos Mt., including adjacent Aegean and south Ionian islands); L. trilineata major Boulenger, 1887 (west of Pindos Mt., including Corfu and Paxos islands); L. trilineata hansschweizeri Müller, 1935 (west Cyclades islands: Milos, Kimolos, Polyegos, Kithnos, Serifos, Sifnos); L. trilineata polylepidota Wettstein, 1952 (Crete and Kythera island); L. citrovittata Werner, 1935 (central Aegean islands: Andros, Tinos, Syros, Mykonos, Naxos, Paros, Antiparos, Ios, possibly other islands); L. diplochondrodes diplochondrodes Wettstein, 1953 (Rhodos and Kos islands); L. diplochondrodes cariensis Peters, 1964 (Samos, Chios, Lesbos islands); L. diplochondrodes dobrogica Fuhn et Mertens, 1959 (northeast Greece).

The snake-eyed lizard, Ophisops elegans Ménétries, 1832 (oфí $\sigma \omega \psi)$ (Fig. 8) is a small lizard common to the eastern Aegean islands. It is a very thermophilic species, observable in bushy open environments and arid fields. In the Dodecanese, we find the subspecies $O$. elegans macrodactylus Berthold, 1842 on Astypalea, Patmos, Arki, Agathonisi, Leros, Kalymnos, Telendos, Kos, Nisyros, Symi, Seskli, Tilos (with the islet of Gaidouronisi), Rhodes, Alimia and Karpathos.

The Erhard's wall lizard Podarcis erhardii (Bedriaga, 1876) ( $\sigma \iota \lambda \imath \beta o v i \tau)$ is highly diversified in Greece and especially in the southern Aegean region. This species shows a great morphological and ecological plasticity and inhabits many different 
habitats. Out of the 28 recognized subspecies, 27 are found in Greece. It is present on the mainland and in many Aegean Islands (North Sporades, Cyclades and Crete), but it is almost completely absent from the Dodecanese, except for Astypalea and its surrounding islets and Pachia and Pergousa, two islets offshore Nisyros (Valakos et al., 1995), which could be a case of recent colonization from the $\mathrm{Cy}$ clades (Poulakakis et al., 2003). Specifically, on Astypalea, Syrna, Dio Adelphi and most likely on Kounoupi and Koutsomyti (pers. obs.) we find $P$. erhardii syrinae (Wettstein, 1937); on Ophidoussa P. erhardii ophidusae (Wettstein, 1937); on Megalo Sofrano $P$. erhardii zafranae (Wettstein, 1937); and on Tria Nisia P. erhardii suboscura (Wettstein, 1937). Also found on Kinaros is P. erhardii kinarensis (Wettstein, 1937), and on Levitha, P. erhardii levithensis (Wettstein, 1937).

The family Scincidae in the Dodecanese Archipelago is represented by four species: Ablepharus kitaibelii (Bibron \& Bory, 1833) ( $\alpha \beta \lambda \varepsilon ́ \varphi \alpha \rho \circ \varsigma)$,

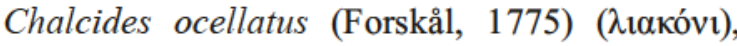
Ophiomorus punctatissimus (Bibron \& Bory, 1833) (офı́ $\mu$ оро૬) and Heremites auratus (Linnaeus,

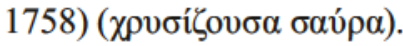

Regarding Ablepharus kitaibelii, on Kos, Leros, Astypalea (Grano \& Cattaneo, 2019a), Makronisi (SW of Lipsi) (Foufopoulos, 1997), Nisyros (Cattaneo, 2006), Tilos (Masseti, 1999), Chalki, Alimia, Symi and Rhodes we find Ablepharus kitaibelii kitaibelii (Bibron \& Bory, 1833). On Karpathos, Kasos, Armathia and Mikronisi (islet of Crete) instead we find Ablepharus kitaibelii fabichi (Štěpánek, 1937). On the island group of Kastellorizo and on the opposite southwest coast of Turkey some individuals of the snake-eyed skink were collected, perhaps belonging to a clade with features of both $A$. kitaibelii and $A$. budaki, which could be ascribed to $A$. (budaki) anatolicus Schmidtler, 1997 and suggests a case of cryptic species that requires further study (Skourtanioti et al., 2016). The snake-eyed skink is usually found in maquis, phrygana and on the ground in leaf litter. It has also been observed in inhabited areas, probably driven there by the increased moisture present.

The ocellated skink Chalcides ocellatus (Forskål, 1775) is a large skink that is frequently encountered on sandy beaches and in cultivated areas, gardens and leaf litters on Nisyros (Cattaneo,
2006), Rhodes, Pentanisos, Karpathos and Kasos (Kornilios \& Thanou, 2016).

The golden skink Heremites auratus (Linnaeus, 1758) (Fig. 9) is a species with an eastern distribution and in the Dodecanese is found on Kos, Symi, Rhodes and Kastellorizo. It usually lives in damp places, such as cultivated areas or grasslands near rivers and streams, but it can be also observed between stone walls. Less terrestrial than the previous species, they rarely share the same habitat.

Ophiomorus punctatissimus (Bibron \& Bory, 1833 ) is a limbless skink that occurs in Greece (primarily on the mainland) and south westernTurkey. On the Aegean Islands, it is found only on Kythera and Kastellorizo. Recent genetic and morphological studies have highlighted the divergences between the western and the eastern populations of $O$. punctatissimus, which has led to the identification of the Anatolian population and the population of Kastellorizo, as a separate species: $O$. kardesi (Kornilios, et al., 2018).

Within the family Anguidae, we have the European glass lizard Pseudopus apodus (Pallas, 1775) ( $\tau \varphi \varphi \lambda i ́ \tau \eta \varsigma)$, which in Greece is represented by the subspecies P. apodus thracius (Obst, 1978). In the Dodecanese Archipelago, it is only found on Kos. In 1953, Wettstein reported its occurrence on Rhodes, but since then no other original reports have been made suggesting further inquiry is required. This legless lizard mainly lives in environments with bushy vegetation, but also in dry rocky places, wooded hills, maquis and phrygana.

Blanus strauchi (Bedriaga, 1884) ( $\alpha \mu \varphi i ́ \sigma \beta \alpha \imath v \alpha)$ is the only species belonging to the family Blanidae that occurs in Greece. It lives underground, in places with sand or soft soil. It is a rare species, found on Kalymnos, Kos, Pserimos (Sindaco et al., 2014), Leros, Symi, Nisyros (Cattaneo, 2006), Rhodes and Kastellorizo. On these islands, the species is represented by the nominate form. In 1983, one specimen of Chamaeleo chamaeleon (Linnaeus, 1758) ( $\mu \varepsilon \sigma o \gamma \varepsilon ı \alpha \kappa o ́ \varsigma ~ \chi \alpha \mu \alpha \imath \lambda \varepsilon ́ o v \tau \alpha \varsigma)$ was reported on Rhodes (Bader et al., 2009), but it could be a case of passive introduction. According to the literature, this species has been seen on Crete, Chios and Samos, though its presence has only been confirmed on the last island (Valakos et al., 2008). 


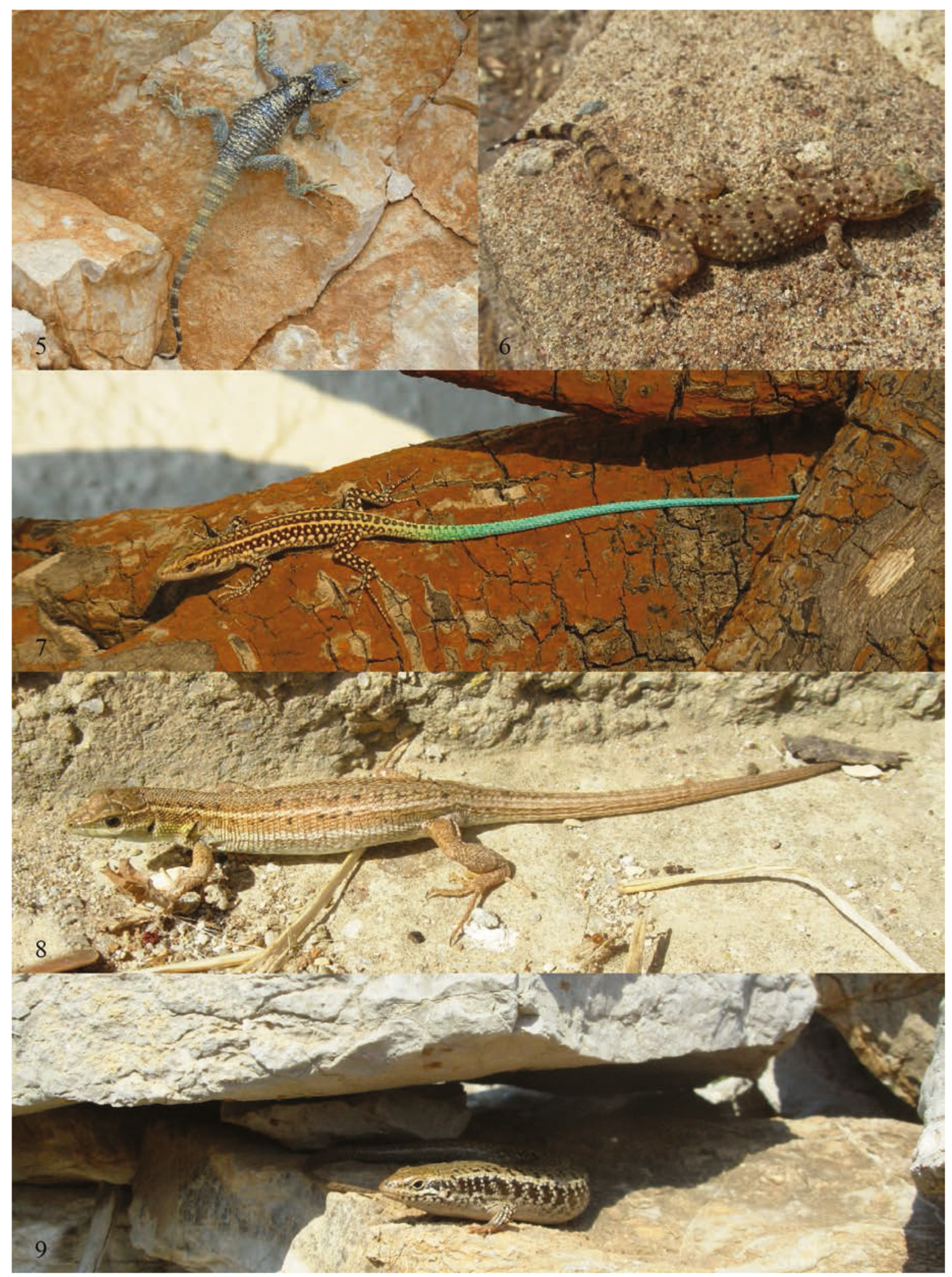

Figure 5. Stellagama stellio (Chalki island). Figure 6. Hemidactylus turcicus (Tilos island). Figure 7. Anatololacerta pelasgiana (Tilos island). Figure 8. Ophisops elegans (Lipsi island). Figure 9. Heremites auratus (Symi island). 


\begin{tabular}{|c|c|c|c|c|c|c|c|c|c|c|c|c|c|c|c|c|c|c|c|c|c|c|c|}
\hline & $\mathbf{A G}$ & AR & PM & LS & LR & KL & TD & PS & ко & $\mathbf{A P}$ & NS & SY & SK & TL & RD & PN & CII & AL & $\mathbf{K P}$ & KS & SR & AM & KT \\
\hline $\begin{array}{l}\text { Lyciasalamandra } \\
\text { helverseni }\end{array}$ & & & & & & & & & & & & & & & & & & & $\mathrm{X}$ & $\mathrm{x}$ & $\mathbf{x}$ & & \\
\hline $\begin{array}{l}\text { Lyciasalamandra } \\
\text { Iuschani }\end{array}$ & & & & & & & & & & & & & & & & & & & & & & & $\mathbf{x}$ \\
\hline $\begin{array}{l}\text { Pelobates } \\
\text { syriacus }\end{array}$ & & & & & & & & & $\mathbf{x}$ & & & & & & & & & & & & & & \\
\hline Bufo bufo & & & & & & & & & $\mathrm{x}$ & & & & & & & & & & & & & & \\
\hline Bufotes viridis & & & & $\mathrm{x}$ & $\mathbf{x}$ & $\mathbf{x}$ & & & $\mathrm{x}$ & & & $\mathrm{x}$ & & $\mathrm{x}$ & $\mathrm{x}$ & & & & & & & & $x$ \\
\hline Hyla orientalis & & & & & & & & & $\mathbf{x}$ & & & & & & $\mathbf{x}$ & & & & & & & & \\
\hline $\begin{array}{l}\text { Pelophylux } \\
\text { bedriagne }\end{array}$ & & & & & & & & & $\mathrm{x}$ & $\mathrm{x}$ & & & & & $\mathrm{x}$ & & & & & & & & \\
\hline $\begin{array}{l}\text { Pelophylax } \\
\text { cerigensis }\end{array}$ & & & & & & & & & & & & & & & & & & & $\mathrm{x}$ & & & & \\
\hline Testudo graeca & & & & & $\mathrm{x}$ & $\mathrm{x}$ & & & $\mathrm{x}$ & & & $\mathrm{x}$ & $x$ & & & & & & & & & & \\
\hline Emys orbicularis & & & & & & & & & $\mathrm{x}$ & & & & & & & & & & & & & & \\
\hline $\begin{array}{l}\text { Maurenys } \\
\text { rivulata }\end{array}$ & & & & & & & & & $\mathbf{x}$ & & & $\mathbf{x}$ & & $\mathbf{x}$ & $\mathbf{x}$ & & $\mathbf{x}$ & & & & & & \\
\hline $\begin{array}{l}\text { Trionyx } \\
\text { triunguix }\end{array}$ & & & & & $\mathrm{x}$ & $\mathbf{x}$ & & & $\mathrm{x}$ & & & & & & $x$ & & & & & & & & \\
\hline $\begin{array}{l}\text { Stellagama } \\
\text { stellio }\end{array}$ & $\mathrm{x}$ & & $\mathrm{x}$ & & $\mathbf{x}$ & $\mathrm{x}$ & $\mathrm{x}$ & & $\mathbf{x}$ & & $\mathrm{x}$ & $\mathrm{x}$ & $\mathrm{x}$ & $\mathrm{x}$ & $\mathrm{x}$ & & $\mathrm{x}$ & $\mathbf{x}$ & $\mathbf{x}$ & & & & $\mathrm{x}$ \\
\hline $\begin{array}{l}\text { Hemidactylus } \\
\text { turcicus }\end{array}$ & $\mathrm{x}$ & $\mathrm{x}$ & $\mathrm{x}$ & $\mathrm{x}$ & $\mathrm{x}$ & $\mathrm{x}$ & & & & $\mathrm{x}$ & $\mathrm{x}$ & $\mathrm{x}$ & & $\mathrm{x}$ & $\mathrm{x}$ & & $\mathrm{x}$ & $\mathrm{x}$ & $\mathrm{x}$ & $\mathbf{x}$ & & & $\mathrm{x}$ \\
\hline $\begin{array}{l}\text { Mediodactylus } \\
\text { kotschyi (s.l.) }\end{array}$ & $\mathrm{x}$ & & & & & $\mathbf{x}$ & & & $\mathbf{x}$ & $\mathrm{x}$ & & $\mathrm{x}$ & & $\mathrm{x}$ & & & $\mathrm{x}$ & & $\mathrm{x}$ & $\mathrm{x}$ & $\mathrm{x}$ & & $\mathrm{x}$ \\
\hline $\begin{array}{l}\text { Anatololacerta } \\
\text { pelasgiana }\end{array}$ & & & & & & & & & & & $\mathrm{x}$ & $\mathrm{x}$ & $\mathrm{x}$ & $\mathrm{x}$ & $\mathrm{x}$ & $\mathrm{x}$ & & $\mathrm{x}$ & & $\mathrm{x}$ & & & $\mathrm{x}$ \\
\hline $\begin{array}{l}\text { Lacerta } \\
\text { diplochondrodes }\end{array}$ & & & & & & & & & $\mathbf{x}$ & & & & & & $\mathbf{x}$ & & & & & & & & \\
\hline Ophisops elegans & $\mathbf{x}$ & $\mathbf{x}$ & $\mathbf{x}$ & & $\mathbf{x}$ & $\mathbf{x}$ & $\mathbf{x}$ & & $\mathbf{x}$ & $\mathbf{x}$ & $\mathbf{x}$ & $\mathbf{x}$ & $\mathbf{x}$ & $\mathbf{x}$ & $\mathbf{x}$ & & & $\mathbf{x}$ & $\mathbf{x}$ & & & & \\
\hline Podarcis erhardii & & & & & & & & & & $\mathbf{X}^{\prime \prime}$ & & & & & & & & & & & & & \\
\hline $\begin{array}{l}\text { Ablepharus } \\
\text { kitaibelii }\end{array}$ & & & & & $\mathbf{x}$ & & & & $\mathbf{x}$ & $\mathrm{x}$ & $\mathbf{x}$ & $\mathrm{x}$ & & $\mathrm{x}$ & $\mathbf{x}$ & & $\mathbf{x}$ & $\mathrm{x}$ & $\mathbf{x}$ & $\mathbf{x}$ & & $\mathbf{x}$ & $\mathbf{X}^{*}$ \\
\hline $\begin{array}{l}\text { Chalcides } \\
\text { ocellatus }\end{array}$ & & & & & & & & & & & $\mathrm{x}$ & & & & $\mathrm{x}$ & $\mathrm{x}$ & & & $\mathrm{x}$ & $\mathrm{x}$ & & & \\
\hline $\begin{array}{l}\text { Heremites } \\
\text { auratus }\end{array}$ & & & & & & & & & $\mathbf{x}$ & & & $\mathrm{x}$ & & & $\mathrm{x}$ & & & & & & & & $\mathrm{x}$ \\
\hline $\begin{array}{l}\text { Ophiomorus } \\
\text { kardesi }\end{array}$ & & & & & & & & & & & & & & & & & & & & & & & $\mathrm{x}$ \\
\hline $\begin{array}{l}\text { Pseudopus } \\
\text { apodus }\end{array}$ & & & & & & & & & $\mathrm{x}$ & & & & & & & & & & & & & & \\
\hline Blanus strauchi & & & & & $\mathbf{x}$ & $\mathrm{x}$ & & $\mathrm{x}$ & $\mathbf{x}$ & & $\mathbf{x}$ & $\mathrm{x}$ & & & $\mathrm{x}$ & & & & & & & & $\mathrm{x}$ \\
\hline
\end{tabular}

Table 1. Amphibians, Tortoises and Lizards of the Dodecanese Archipelago (the brackets indicate "presence to be confirmed"). Legend: $A G=$ Agathonisi; $A R=$ Arki; $\mathrm{PM}=$ Patmos; $\mathrm{LS}=\mathrm{Lipsi} ; \mathrm{LR}=$ Leros; $\mathrm{KL}=$ Kalymnos; TD $=$ Telendos; $\mathrm{PS}$ $=$ Pserimos $; \mathrm{KO}=$ Kos; $\mathrm{AP}=$ Astypalea; $\mathrm{NS}=$ Nisyros; $\mathrm{SY}=$ Symi; $\mathrm{SK}=$ Seskli; $\mathrm{TL}=$ Tilos; $\mathrm{RD}=$ Rodi; $\mathrm{PN}=$ Pentanisos; $\mathrm{CH}=$ Chalki; $\mathrm{AL}=$ Alimia $\mathrm{KP}=$ Karpathos; $\mathrm{KS}=\mathrm{Kasos} ; \mathrm{SR}=$ Saria $; \mathrm{AM}=$ Armathia $; \mathrm{KT}=$ Kastellorizo. ${ }^{*}=\mathrm{The}$ populations of Kastellorizo Island could belong to a different species. \# = The neighboring islets are also included.

\section{Snakes}

Thirteen snake species have been reported in the Dodecanese.

The European blind snake, Xerotyphlops ver-

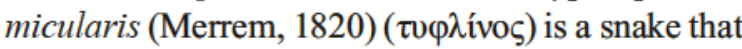
resembles an earthworm, and is adapted to live underground. It has been reported on Patmos, Leros, Kalymnos, Kos, Symi and Rhodes. The species also occurs on some islands off the south western Turkish coast like Domuz, Tersane and Kizkumu (Lo Cascio \& Masseti, 2004).

The Javelin sand boa, Eryx jaculus (Linnaeus, 1758) ( $(\varepsilon v \xi)$ (Fig. 10), is the only boa species in Europe. This species, much smaller than its "relatives", has been reported on Leros, Kalymnos and Kos, where it is represented by the subsp. turcicus (Olivier, 1801). 
The European whip snake, Dolichophis caspius (Gmelin, 1789) (ź $\varphi 10 \varsigma$ ) (Fig. 11), is one of the most common snake species. It is a diurnal snake and easily observed, being found in gardens, farms and cultivated lands. In the Dodecanese it has been reported on Agathonisi, Patmos, Kalymnos, Kos, Nisyros and Karpathos. On Nisyros, in addition to specimens with the typical colouring, we also find adult individuals with dorsal spots that vary in pattern from those found in juveniles and are comparable only to the specimens found on the Ionian island of Corfù (Cattaneo, 2006).

The black whip snake, Dolichophis jugularis (Linnaeus, 1758) ( $\mu \alpha v ́ \rho \operatorname{sos} \dot{\varphi} 10 \zeta$ ), is one of the biggest European snakes. It is found only in the Dodecanese and particularly on Leros, Kos, Tilos, Symi, Rhodes, Chalki and Kastellorizo. Its presence is also highly likely on the small islands of Alimia and Seskli. It is also found on the island of Göcek (SW Turkey) (Lo Cascio \& Masseti, 2004). On Kos Island, $D$. jugularis coexists with its sister species $D$. caspius. In this case both whip snakes seem to have mostly non-overlapping habitats, with $D$. caspius being more common along wet coastal stretches, and D. jugularis mostly seeking out hilly inland areas. Even so, being generic this spatial separation would not exclude areas of syntopy (Cattaneo, 2005b). In the Rhodes Archipelago (Rhodes, Symi, Tilos, Chalki) the endemic subspecies zinneri Cattaneo, 2012 is found, mainly characterized by a lessintense colouring than that of the nominate form, both dorsally and ventrally (and often having a yellow belly instead of red). A different head morphometry and a lower number of ventral scales are other distinctive features. On Kos and Leros the nominate subspecies occurs (Cattaneo, 2012).

The ringheaded dwarf snake, Eirenis modestus (Martin, 1838) ( $\theta \alpha \mu v o ́ \varphi ı$ o) (Fig. 12), is a small snake that can be observed in bushes or under stones. It has been reported on Leros, Kalymnos, Symi, Seskli and Kastellorizo. It is also found on Kameriye Island (SW Turkey) (Lo Cascio \& Masseti, 2004). On the islands of the eastern Aegean arc (and therefore also in the Dodecanese) the subspecies semimaculatus (Boettger, 1876) occurs with two phenotypes: one spotless and one with dark spots distributed on the first half of the body. Melanotic specimens have also been found on the island of Kastellorizo (Kalaentzis et al., 2018a).

The coin snake, Hemorrhois nummifer (Reuss,

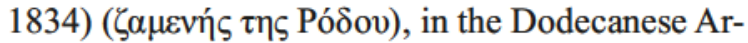
chipelago is found on Patmos, Lipsi, Leros, Kalymnos, Kos, Symi, Rhodes and Kastellorizo. This snake has a colouring that resembles that of Montivipera xanthina, with which it shares a good part of its range (Aegean-Anatolian distribution). Certainly, its aesthetic similarity to the viper deters predators and increases the snake's fitness (Schätti \& Agasian, 1985).

The Dahl's whip snake, Platyceps najadum (Eichwald, 1831) ( $\sigma \alpha i ́ \tau \alpha)$, is a very slender snake. It has been observed on Arki, Patmos, Lipsi, Leros, Kalymnos, Kos, Nisyros and Rhodes. The population of Kalymnos Island exhibits a particular polymorphism (a dark phenotype and a dark olive-grey one) that in the past led to its allocation to the subsp. kalymnensis (Schneider, 1979) (Cattaneo, 2005a). The Rhodes population seems to belong to the nominate form (adults with iron-grey colour). On all the other Dodecanese Islands, the subsp. dahlii (Schinz, 1833 ) is present.

The cat snake, Telescopus fallax (Fleischmann, 1831) ( $\alpha \gamma$ เó so easily observable as it is active during the night. It is found on Lipsi, Kalymnos, Kos, Pserimos, Tilos, Symi, Rhodes, Karpathos, Kasos and Armathia. On Rhodes, Tilos, Kasos and perhaps on Symi and Armathia, there is the endemic subsp. rhodicus Wettstein, 1952, characterized, among other things, by its dull and low-contrast colours, a probable expression of its adaptation to dry environments (Grano et al., 2018).

The leopard snake, Zamenis situla (Linnaeus,

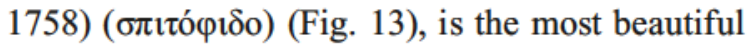
European snake. In the Dodecanese Archipelago it has been reported on Kos, Rhodes and Chalki (Grano \& Cattaneo, 2015). There are two morphs for this species: one spotted (phenotype leopardinus) and the other striped (phenotype situla); even though they can be found together on the same island, the first seems to be more common on Rhodes and Chalki, and the latter on Kos (Zavattari, 1929).

In the Dodecanese both of the water snakes found in Greece have also been reported. The grass

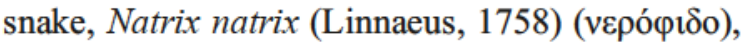
is a very common species in Europe and Asia Minor. Its habitat is close to wetlands and, especially in Rhodes, it can be found next to rivers and streams. It has also been reported on Leros, Kos and Karpathos. On these islands, the species is repre- 


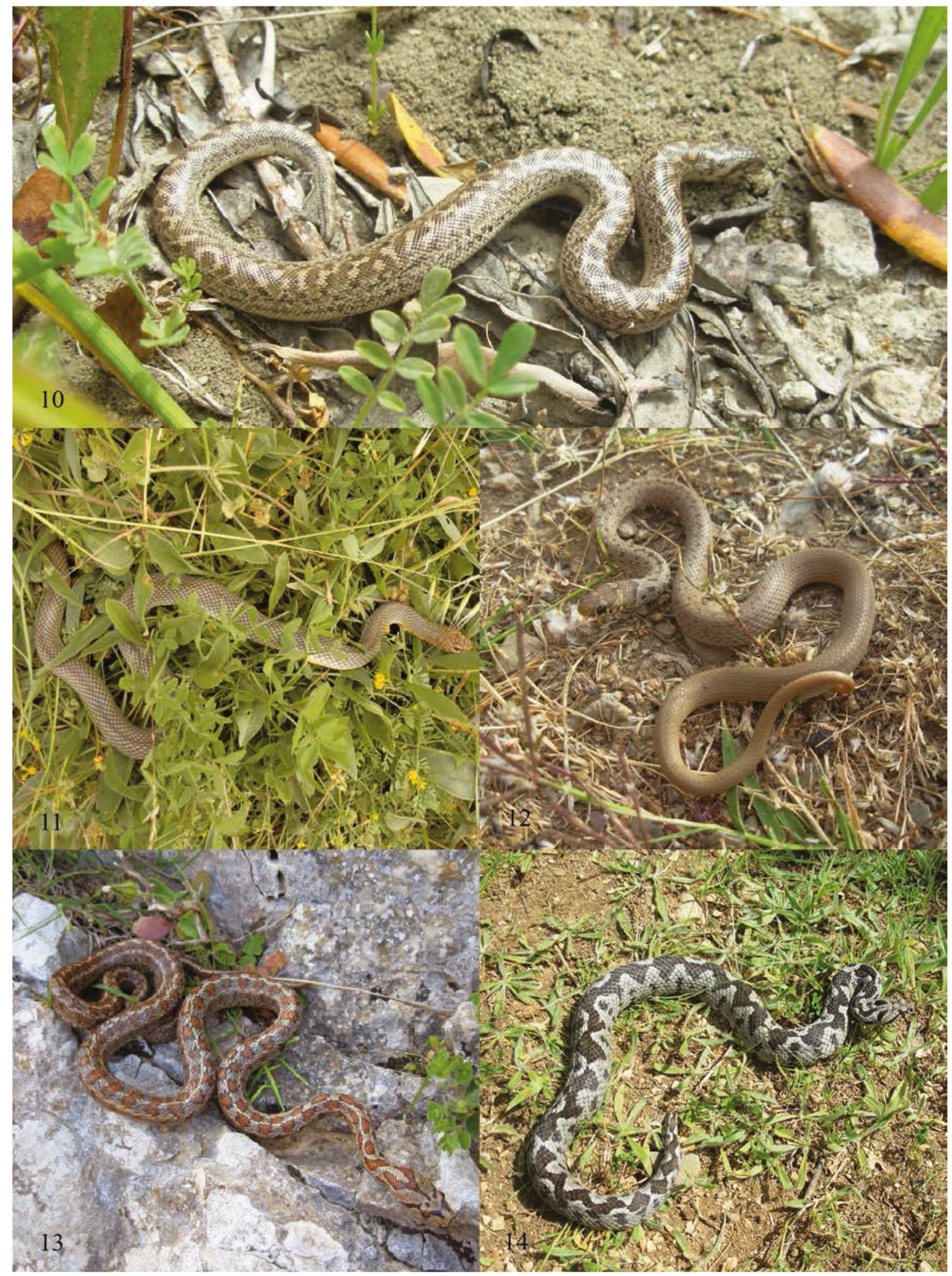

Figure 10. Eryx jaculus (Leros island). Figure 11. Dolicophis caspius (Patmos island). Figure 12. Eirenis modestus (Symi island). Figure 13. Zamenis situla (Chalki island). Figure 14. Montivipera xanthina (Symi island). 
sented by the subsp. persa (Pallas, 1814), also characterized by two clearly marked stripes along the back, with the exception of the specimens from Karpathos which lack stripes (Bogaerts et al., 2018). A dead specimen of $N$. natrix on the island of Kasos has been found from the authors in August 2019 (Grano \& Cattaneo, 2020). The specimen lacked of longitudinal stripes, resembling the phenotype of the specimens found in Karpathos.

On Rhodes, the dice snake Natrix tessellata (Laurenti, 1768) ( $\lambda \iota \mu v o ́ \varphi ı \delta o)$, more adapted to "aquatic" life, can also be found. Where these two species of Natrix coexist, their complementary diets make them ecologically compatible: $N$. natrix mainly looks for batrachians while $N$. tessellata mostly for fish. The current presence, however, of $N$. tessellata on Rhodes needs to be confirmed.

The eastern montpellier snake, Malpolon in-

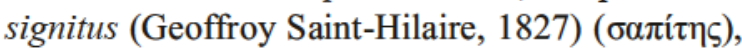
is a common large snake. It is found on Kalymnos (Broggi, 1997), Kos and Kastellorizo. On these islands, the species is represented by the subsp. fuscus (Fleischmann, 1831), which is smaller in size compared to the westernmost forms of the genus
Malpolon. It is worth noting that in nature, even at an adequate distance for observation, this snake could be easily confused with Dolichophis caspius, especially if young or sub-adult.

The Ottoman viper or coastal viper, Montivipera

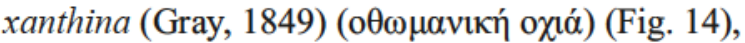
is the only snake that could pose a danger to man due to its potent venom. In general, however, vipers do not bite unless they feel threatened or disturbed. This viper species is present on mainland Greece, such as in Rhodope and Evros (Cattaneo, 2017), and on some islands of the Eastern Aegean like in the Dodecanese Archipelago. More specifically, it has been reported on Patmos, Lipsi, Leros, Kalymnos, Kos and Symi. A young specimen was also detected on Tilos Island (Broggi, 2006). Along the eastern Aegean arc, the species shows great variability (Cattaneo, 2014): on Chios the subsp. nilsoni Cattaneo, 2014, is larger in size; on Leros the subspecies dianae Cattaneo, 2014, is present and characterized, among other things, by its larger body circumference. Furthermore, on Lipsi, a particular morphotype with exceptional features has also been detected (Cattaneo, 2018).

\begin{tabular}{|c|c|c|c|c|c|c|c|c|c|c|c|c|c|c|c|c|c|c|c|}
\hline & AG & AR & $\mathbf{P M}$ & LS & LR & KL & PS & KO & NS & SY & SK & TL & RD & $\mathrm{CH}$ & AL & KP & KS & AM & KT \\
\hline Xerotyphlos vermicularis & & & $\mathrm{X}$ & & $\mathrm{x}$ & $\mathrm{x}$ & & $\mathrm{x}$ & & $\mathbf{x}$ & & & $\mathrm{x}$ & & & & & & \\
\hline Eryx jaculus & & & & & $\mathrm{x}$ & $\mathrm{x}$ & & $\mathrm{x}$ & & & & & & & & & & & \\
\hline Dolichophis caspius & $\mathrm{x}$ & & $\mathrm{x}$ & & & $\mathrm{x}$ & & $\mathrm{x}$ & $\mathrm{x}$ & & & & & & & $\mathrm{x}$ & & & \\
\hline Dolichophis jugularis & & & & & $\mathrm{x}$ & & & $\mathrm{x}$ & & $\mathrm{x}$ & $(\mathrm{X})$ & $\mathrm{X}$ & $\mathrm{x}$ & $\mathbf{x}$ & (X) & & & & $\mathrm{x}$ \\
\hline Eirenis modestus & & & & & $\mathrm{X}$ & $\mathrm{x}$ & & & & $\mathrm{x}$ & $\mathrm{x}$ & & & & & & & & $\mathrm{X}$ \\
\hline Hemorrhois nummifer & & & $\mathrm{x}$ & $\mathrm{x}$ & $\mathrm{x}$ & $\mathrm{x}$ & & $\mathrm{x}$ & & $\mathrm{x}$ & & & $\mathrm{x}$ & & & & & & $\mathrm{x}$ \\
\hline Platyceps najadum & & $\mathrm{x}$ & $\mathrm{x}$ & $\mathrm{x}$ & $\mathrm{x}$ & $\mathrm{x}$ & & $\mathrm{x}$ & $\mathrm{x}$ & & & & $\mathrm{x}$ & & & & & & \\
\hline Telescopus fallax & & & & $\mathrm{x}$ & & $\mathrm{x}$ & $\mathrm{x}$ & $\mathrm{x}$ & & $\mathrm{x}$ & & $\mathrm{x}$ & $\mathrm{x}$ & & & $(\mathrm{X})$ & $\mathrm{x}$ & $\mathrm{x}$ & \\
\hline Zamenis situla & & & & & & & & $\mathrm{X}$ & & & & & $\mathrm{x}$ & $\mathrm{X}$ & & & & & \\
\hline Natrix natrix & & & & & $\mathrm{x}$ & & & $\mathrm{x}$ & & & & & $\mathrm{x}$ & & & $\mathrm{X}$ & $\mathrm{X}$ & & \\
\hline Natrix tessellata & & & & & & & & & & & & & $(\mathrm{X})$ & & & & & & \\
\hline Malpolon insignitus & & & & & & $\mathrm{x}$ & & $\mathrm{x}$ & & & & & & & & & & & $\mathrm{X}$ \\
\hline Montivipera xanthina & & & $\mathrm{X}$ & $\mathrm{x}$ & $\mathrm{X}$ & $\mathrm{X}$ & & $\mathrm{X}$ & & $\mathrm{X}$ & & $(\mathbf{X})$ & & & & & & & \\
\hline
\end{tabular}

Table 2. The snakes of the Dodecanese Archipelago (the brackets indicate "presence to be confirmed"). Legend: AG= Agathonisi; AR = Arki; PM = Patmos; LS = Lipsi; LR = Leros; KL = Kalymnos; PS = Pserimos; KO = Kos; NS = Nisyros; $\mathrm{SY}=$ Symi; $\mathrm{SK}=$ Seskli; $\mathrm{TL}=$ Tilos; $\mathrm{RD}=$ Rodi; $\mathrm{CH}=$ Chalki; $\mathrm{AL}=\mathrm{Alimia} ; \mathrm{KP}=$ Karpathos; $\mathrm{KS}=\mathrm{Kasos} ; \mathrm{AM}=$ Armathia; KT = Kastellorizo. 


\section{REFERENCES}

Agasyan A., Tuniyev B., Isailovic J.C., Lymberakis P., Andrén C., Cogalniceanu D., Wilkinson J., Ananjeva N., Üzüm N., Orlov N., Podloucky R., Tuniyev S. \& Kaya U., 2009. Pelobates syriacus. The IUCN Red List of Threatened Species, 2009: e.T58053A11723 660. http://dx.doi.org/10.2305/IUCN.UK.2009.RL TS.T58053A11723660.en. Downloaded on 08 October 2018 .

Bader T., Riegler C. \& Grillitsch H., 2009. The herpetofauna of the island of Rhodes (Dodecanese, Greece). Herpetozoa, 21: 147-169.

Bellati A., Carranza S., Garcia-Porta J., Fasola M. \& Sindaco R., 2015. Cryptic diversity within the Anatololacerta species complex (Squamata: Lacertidae) in the Anatolian Peninsula: Evidence from a multi-locus approach. Molecular phylogenetics and evolution, 82: 219-233. https://doi.org/10.1016/j.ympev.2014. 10.003

Bogaerts S., Pasmans F., Protopapas D., Pafilis P. \& Lymberakis P., 2018. Rediscovery of the grass snake (Natrix natrix) on the island of Karpathos, Greece. Herpetology Notes, 11: 303-305.

Broggi M., 1997. Notizen zur Herpetofauna von Kalymnos und Leros (Dodekanes, Griechenland). Herpetozoa, 10: 135-138.

Broggi M., 2006. Isolation und Landnutzungswandel und ihre Einflüsse auf die Herpetofauna - dargestellt am Beispiel der Insel Tilos (Dodekanes, Griechenland). Herpetozoa, 19: 13-16.

Broggi M., 2008. The herpetofauna of Lipsi (Dodecanese, Greece) and nature conservation aspects. Herpetozoa, 21: 79-84.

Broggi M., 2012. The Balkan Terrapin Mauremys rivulata (Valenciennes, 1833), in the Aegean islands. Threats, conservation aspects and the situation on the island of Kea (Cyclades) as a case study (Testudines: Geoemydidae). Herpetozoa, 24: 149-163.

Broggi M. \& Grillitsch H., 2012. The European Pond Terrapin Emys orbicularis hellenica (Valenciennes,1832) in the Aegean: Distribution and threats. Herpetozoa, 25: 47-58.

Cattaneo A., 2005a. Nuovo contributo alla conoscenza dell'erpetofauna dell'isola egea di Kalymnos (Sporadi meridionali). Bollettino del Museo civico di storia naturale di Venezia, 56: 153-163.

Cattaneo A., 2005b. Observations on the herpetofauna of the Greek island of Kos (southern Sporades) with an unpublished case of microinsular sympatry of two closely related coloubridae species: Hierophis caspius (Gmelin) and Hierophis jugularis (L.). Atti Storia naturale della Maremma, 21: 79-91.

Cattaneo A., 2006. Contributo alla conoscenza dell'erpetofauna dell'isola egea di Nisyros (Dodecaneso) (Reptilia). Il Naturalista siciliano, 30: 485-494.
Cattaneo A., 2008. Osservazioni sull'ofidiofauna delle isole egee di Leros e Patmos (Dodecaneso) (Reptilia Serpentes). Il Naturalista siciliano, 32: 201-219.

Cattaneo A., 2009. L'ofidiofauna delle isole egee di Halki e Tilos (Dodecaneso) con segnalazione di un nuovo fenotipo di Dolichophis jugularis (Linnaeus) (Reptilia Serpentes). Il Naturalista siciliano, 33: 131-147.

Cattaneo A., 2012. Il colubro gola rossa dell'arcipelago di Rodi: Dolichophis jugularis zinneri subsp. nova (Reptilia Serpentes). II Naturalista siciliano, 34: 77103.

Cattaneo A., 2014. Variabilità e sottospecie di Montivipera xanthina (Gray, 1849) nelle isole egee orientali (Reptilia Serpentes Viperidae). Il Naturalista siciliano, 38: 51-83.

Cattaneo A., 2017. Note sull'erpetofauna dell'Evros sudoccidentale (Grecia NE) e nuovo contributo alla conoscenza di Montivipera xanthina (Gray, 1849) della Tracia greca centro-orientale, con descrizione di Montivipera xanthina occidentalis subsp. nova (Reptilia Serpentes Viperidae). Il Naturalista siciliano, 41: 53-74.

Cattaneo A., 2018. L'erpetofauna (Reptilia) delle isole egee di Oinousses (Egeo nordorientale) e di Lipsi (Dodecaneso settentrionale). Il Naturalista siciliano, 42: 15-39.

Corsini-Foka M. \& Masseti M., 2008. On the oldest known record of the Nile Soft-shelled Turtle, Trionyx triunguis (Forskål, 1775), in the Eastern Aegean islands (Greece), Zoology in the Middle East, 43: 108110. https://doi.org/10.1080/09397140.2008.1063 82 76

Dimaki M., 2002. Herpetofauna of Rhodes and the rest of the Dodecanese. In: Masseti M. (Ed.), Island of deer. Natural history of the fallow deer of Rhodes and of the vertebrates of the Dodecanese (Greece). City of Rhodes, Environmental Organization, Rhodes: 63-69.

Džukic G., Beškov V., Sidrovska V., Cogalniceanu D. \& Kalezic M.L., 2008. Contemporary chorology of the spadefoot toads (Pelobates spp.) in the Balkan Peninsula, Zeitschrift fur Feldherpetologie, 15: 61-78.

Foufopoulos J., 1997. The reptile fauna of the northern Dodecanese (Aegean islands, Greece). Herpetozoa, 10: 3-12.

Grano M., Cattaneo C. \& Cattaneo A., 2015. First observations on the herpetological and theriological fauna of Alimia Island (Rhodes Archipelago, Aegean Sea), Biodiversity Journal, 6: 73-78.

Grano M. \& Cattaneo C., 2015. First record of Zamenis situla (Linnaeus, 1758) (Reptilia Serpentes) for the Aegean Island of Chalki (Dodecanese, Greece). Il Naturalista siciliano, 39: 375-381.

Grano M. \& Cattaneo C., 2017. The Balkan Terrapin Mauremys rivulata (Valenciennes in Bory de Saint- 
Vincent, 1833) (Testudines Geoemydidae) in the Aegean island of Chalki: native or introduced? Biodiversity Journal, 8: 851-854.

Grano M., Cattaneo C. \& Cattaneo A., 2018. Nuovo contributo alla conoscenza dell'erpetofauna dell'isola egea di Tilos (Dodecaneso, Grecia) (Amphibia et Reptilia). Il Naturalista Siciliano, 42: 3-13.

Grano M. \& Cattaneo C., 2019a. First evidence for the snake-eyed skink Ablepharus kitaibelii (Bibron et Bory de Sant-Vincent, 1833) (Sauria Scincidae) in Astypalea Island (Dodecanese, Greece). Biodiversity Journal, 10: 3-6. https://doi.org/10.31396/Biodiv. Jour. 2019.10.1.3.6.

Grano M. \& Cattaneo C., 2019b. First record of the Roughtailed agama Stellagama stellio (Linnaeus, 1758) (Reptilia, Agamidae) from Karpathos island (Dodecanese, Greece). Parnassiana Archives, 7: 51-54.

Grano M. \& Cattaneo C., 2020. A new record of the grass snake, Natrix natrix (Linnaeus, 1758) (Squamata, Serpentes) in Kasos island (Dodecanese Greece). Parnassiana Archives, 8: 13-16.

Kalaentzis K., Kazilas C. \& Strachinis I., 2018a. Two cases of melanism in the Ring-headed Dwarf Snake Eirenis modestus (Martin, 1838) from Kastellorizo, Greece (Serpentes: Colubridae). Herpetology Notes, 11: $175-178$.

Kalaentzis K., Strachinis I., Katsiyiannis P., Oefinger P., \& Kazilas C., 2018b. New records and an updated list of the herpetofauna of Kastellorizo and the adjacent islet Psomi (Dodecanese, Greece). Herpetology Notes, 11: 1009-1019.

Kornilios P. \& Thanou E., 2016. Two Additions to the Herpetofauna of Kasos (Aegean Sea, Greece) and the Role of Human-mediated Dispersals. Herpetological Review, 47: 633-635.

Kornilios P., Thanou E., Lymberakis P., Ilzag Ç., Kumlutaş Y. \& Leaché A., 2019. A phylogenomic resolution for the taxonomy of Aegean green lizards. Zoologia Scripta, 00: 1-14. https://doi.org/10.1111 /zsc. 12385

Kornilios P., Kumlutaş Y., Lymberakis P. \& Ilgaz Ç., 2018. Cryptic diversity and molecular systematics of the Aegean Ophiomorus skinks (Reptilia: Squamata), with the description of a new species. Journal of Zoological Systematics and Evolutionary Research, 56: 364-381. https://doi.org/10.1111/jzs.12205

Kotsakiozi P., Jablonskic D., Ilgazd Ç., Kumlutaşd Y., Avcre A., Meiri S., Itescu Y., Kukushkinh O., Gvoždík V., Scillitani G., Roussos S.A., Jandzik D., Kasapidis P., Lymberakis P. \& Poulakakis N., 2018. Multilocus phylogeny and coalescent species delimitation in Kotschy's gecko, Mediodactylus kotschyi: Hidden diversity and cryptic species. Molecular phylogenetics and evolution, 125: 177-187. https://doi. org/10.1016/j.ympev.2018.03.022
Lo Cascio P. \& Masseti M., 2004. Distributional records for some herpetofaunal species in the islands of SW Turkey, with notes on the diet of Laudakia stellio. Herpetological Bulletin, 87: 25-28.

Lymberakis P., Poulakakis N., Manthalou G., Tsigenopoulos C.S., Magoulas A. \& Mylonas M., 2007. Mitochondrial phylogeography of Rana (Pelophylax) populations in the Eastern Mediterranean region. Molecular phylogenetics and evolution, 44: 115-25.

Lymberakis P., Ugurtas I.H., Papenfuss T., Sparreboom M., Kuzmin S., Anderson S. \& Denoël M., 2009. Lyciasalamandra helverseni. The IUCN Red List of Threatened Species 2009: e.T61918A12572637. http://dx.doi.org/10.2305/IUCN.UK.2009.RLTS. T61918A12572637.en. Downloaded on 07 October 2018.

Masseti M., 1999. Terrestrial vertebrate fauna on Mediterranean islands: Tilos (Dodecanese, Greece) a case study. Abstracts of the 8th International Congress on the Zoogeography and Ecology of Greece and Adjacent Regions. Kavala, 17-21 May 1999. The Hellenic Zoological Society, Athens: 94.

Pafilis P., Kapsalas G., Lymberakis P., Protopapas D. \& Sotiropoulos K., 2019. The Karpathos marsh frog (Pelophylax cerigensis): what does the most endangered frog in Europe eat? Animal and Conservation, 42, 1: 1-8. https://doi.org/10.32800/abc.2019.42. 0001

Papatheodorou F. \& Pagkas N., 2001. Creation of a Natural Park in Tilos for the rescue and enrichment of fauna, flora and indigenous as well as migrating birds. Municipality of Tilos, $324 \mathrm{pp}$.

Poulakakis N., Lymberakis P., Antoniou A., Chalkia D., Zouros E., Mylonas M. \& Valakos E., 2003. Molecular phylogeny and biogeography of the wall-lizard Podarcis erhardii (Squamata: Lacertidae), Molecular Phylogenetics and Evolution, 28: 38-46. https:// doi.org/10.1016/S1055-7903(03)00037-X

Schätti B. \& Agasian A., 1985. Ein neues Konzept für den Coluber ravergieri - C. nummifer Komplex (Reptilia, Serpentes, Colubridae). Zoologische Abhandlungen Museum für Tierkunde, Dresden, 40: 109-123.

Sindaco R., Kornilios P., Sacchi R. \& Lymberakis P., 2014. Taxonomic reassessment of Blanus strauchi (Bedriaga, 1884) (Squamata: Amphisbaenia: Blanidae), with the description of a new species from south-east Anatolia (Turkey), Zootaxa, 3795: 311326. http://dx.doi.org/10.11646/zootaxa.3795.3.6

Skourtanioti E., Kapli P., Ilgaz C., Kumlutaş Y., Avcı A., Ahmadzadeh F., Isailović J.C.N., Gherghel I., Lymberakis P. \& Poulakakis N., 2016. A reinvestigation of phylogeny and divergence times of the Ablepharus kitaibelii species complex (Sauria, Scincidae) based 
on mtDNA and nuDNA genes, Molecular Phylogenetics and Evolution,103: 199-214. http://dx.doi.org /10.1016/j.ympev.2016.07.005

Taşkavak E., Reimann M.J. \& Polder W.N., 1999. First record of Trionyx triunguis from Kos Island, Greece with comments on its occurrence in the eastern Mediterranean, Chelonian Conservation and Biology, 3: $510-512$.

Temple H.J. \& Cox N.A., 2009. European Red List of Amphibians. Office for Official Publications of the European Communities. Luxembourg.

Toli E.A., Siarabi S., Bounas A., Pafilis P., Lymberakis P. \& Sotiropoulos K., 2018. New insights on the phylogenetic position and population genetic structure of the Critically Endangered Karpathos marsh frog Pelophylax cerigensis (Amphibia: Anura: Ranidae), Acta Herpetologica, 13. http://dx.doi.org/10.13128 /Acta_Herpetol-23189.

Valakos E., Maragou P. \& Mylonas M., 1995. Geographical distribution: Podarcis erhardii. Society for the Study of Amphibians and Reptiles. Herpetological Review, 26: 155.

Valakos E., Pafilis P., Sotiropoulos K., Lymberakis P., Maragou P. \& Foufopoulos J., 2008. The Amphibians and Reptiles of Greece. Edition Chimaira, Frankfurt am Main, 463 pp.

Veith M. \& Steinfartz S., 2004. When non-monophyly results in taxonomic consequences - the case of Mertensiella within the Salamandridae (Amphibia: Urodela), Salamandra - German Journal of Herpetology, 40: 67-80.

Zavattari E., 1929. Ricerche faunistiche nelle isole italiane dell'Egeo. Parte seconda. Fauna terrestre e fluviale. Anfibi e Rettili. Archivio zoologico italiano, Torino, 13: 31-36.

\section{APPENDIX}

The large whip snake of the Rhodes Archipelago, Dolichophis jugularis zinneri Cattaneo, 2012

\section{Augusto Cattaneo}

Dolichophis jugularis known formerly mostly as Zamenis gemonesis, so named, e.g., by Bedriaga (1882), Boettger (1888), Calabresi (1923), was known, until recent years, as Coluber jugularis Linnaeus, 1758.

This large snake, which can normally exceed two meters in length and 1500 grams in weight, shows a distribution along the Turkish coast in the southeastern Aegean Islands of Leros, Kos, Rhodes, Symi, Chalki, Tilos, Kastellorizo and conceivably
Alimia and Seskli. Moreover, it has also been found on Cyprus and in the Near and Middle East.

Currently, $D$. jugularis is regarded as a polytypic species, represented by four subspecies: $D$. jugularis jugularis (Linnaeus, 1758) from SW Turkey and the opposite islands of Leros and Kos, eastern Caucasus, northern Iraq and Iran, central and northern Syria) (Fig. 1), D. jugularis asianus (Boettger, 1880) from southern Syria, Jordan, Lebanon, Israel, and the Sinai Peninsula in Egypt, D. jugularis cypriacus (Zinner, 1972) from Cyprus, and D. jugularis zinneri Cattaneo, 2012 from Aegean islands of Rhodes, Symi, Chalki and Tilos (Fig. 1).

Dolichophis jugularis populations inhabiting the Dodecanese Archipelago (Rhodes, Symi, Chalki and Tilos) have always aroused great interest in the herpetologists who have studied them (Wettstein, 1953; Clark, 1992; Bader \& Riegler, 2004; Bader et al., 2009). Indeed, their morphological features, especially those concerning the colouring, differ from those of the neighboring continental populations and northern Dodecanese (Leros, Kos). In this regard, Clark (1990) writes: "On Tilos the snakes are quite different. Those caught, all males, were very nearly black above but the colouring was a dull mat instead of shiny ... The bellies were green/yellow powdered or marked with black ... I postulate that in view of the presence of $\mathrm{C}$. j. jugularis on Karpathos the Tilos populations represent an intermediate form between the two subspecies [back then Dolichophis caspius was regarded as a subspecies of $D$. jugularis, ed.s n.]". Furthermore, while Wilson \& Grillitsch (2009) point out that the populations of Rhodes and Symi are homogeneous in their morphological characteristics, Schlüter (2010) argues: "Die Symi-Population scheint eine Position zwischen $\mathrm{D}$. caspius und D. jugularis einzunehmen. Daher bestehen Probleme bei der taxonomischen Zuordnung. Vielleicht handelt es sich um eine eigene Unterart oder gar kryptische Art'.

The features of the Rhodian populations were noted by Zinner (1972), who thought he could describe them with a new subspecies, which he improperly attributed to $D$. caspius. Indeed, in his dissertation, though never published, the Dolichophis specimens appear under the name Coluber caspius eiselti and are described as follows: black back; upper surface of the head splotchy or spotted; the underside orange to brickred with black dots from the throat to the subcaudal 
region; 189-197 ventrals. From a nomenclatural point of view, the description of Zinner (1972) is not valid (Ščerbak \& Böhme, 1993).

Actually, $D$. jugularis populations inhabiting the Rhodes Archipelago have acquired morpho-physiological and behavioral features that bring them closer to their sister species D. caspius, so much so that it has led, as is the case here, to identification mistakes. Indeed, these specimens have less intense colouring perhaps in response to drier environments, and are more aggressive than the nominate form. Not only that, but they seem to seek the same kind of environments (moist depression in the soil) as D. caspius as well as practice the same by sight hunting habits and

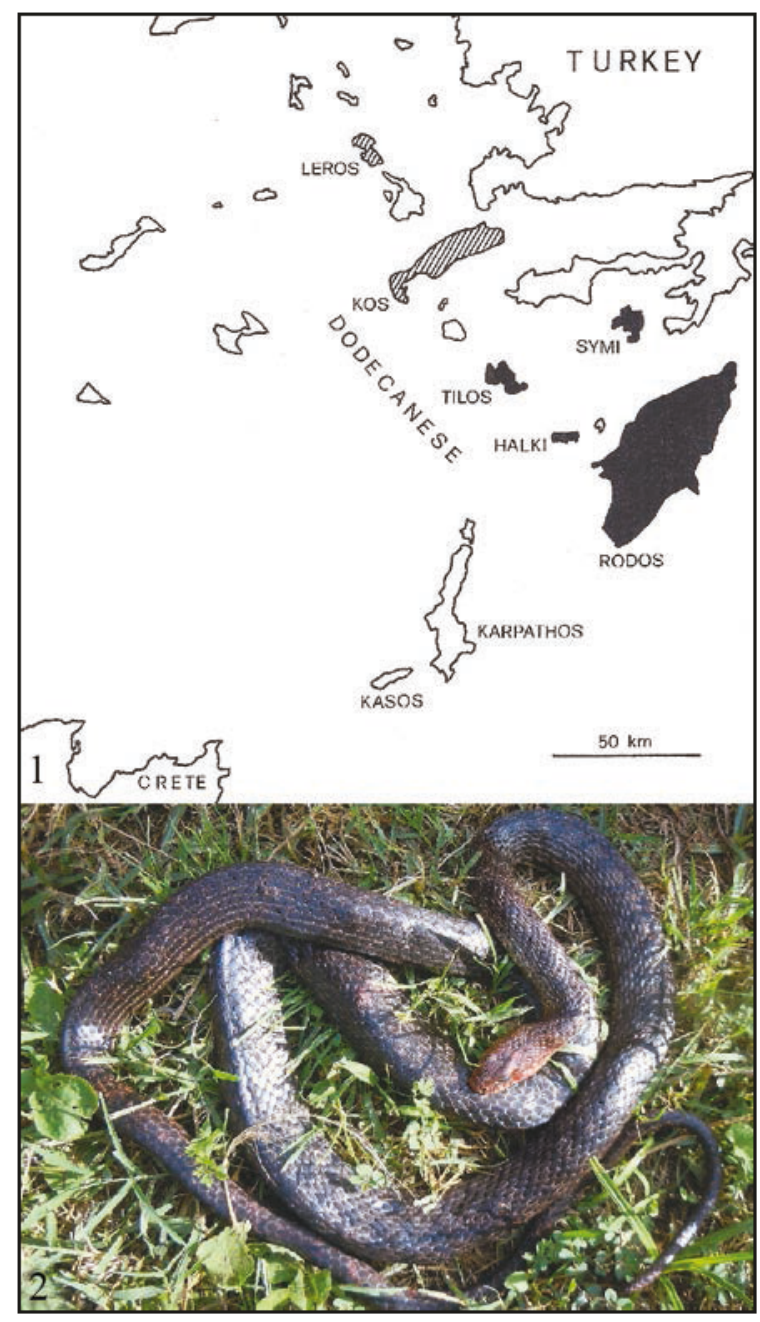

Figure 1. Aegean range of Dolichophis jugularis. The distribution of the nominate form is shown in dotted lines, that of the ssp. zinneri in black. Figure 2. Male adult specimen of $D$. jugularis zinneri from Tilos Island. straight line escape technique, all behaviors also detected by Zinner (1972). At this point it is no wonder that Zinner (1972) ascribed the Rhodian population of Dolichophis to caspius instead of jugularis.

All of these observations and considerations have led to the description of a new geographical subspecies, endemic of Rhodes and of its Archipelago: Dolichophis jugularis zinneri (Cattaneo, 2012), so named in honour of Dr. Hermann Zinner, who though ascribing it to another species, was the first to highlight the specific nature of the Rhodian populations of $D$. jugularis.

The morphological characteristics of the new taxon are summarized below. Dolichophis jugularis zinneri differs from the typical form in that it has a wider head with shorter and pointed muzzle (cephalic index: max length/width of the head, is less then 2, while it is more than 2 in D. jugularis jugularis), and in the colour the supralabials, the sides of the neck and the throat are always yellow (instead of salmon-red) and it has a less intense dark dorsal colour (the basic colour darkens anterior-posteriorly). Also characteristic are: the high occurrence of yellow-bellied phenotypes (the nominate subspecies normally has a red belly), the lower number of ventrals (generally less than 200), and the persistence of the juvenile habitus over $100 \mathrm{~cm}$ of total length. The ventral colour (red or yellow, never black) also helps to distinguish $D$. jugularis zinneri from both $D$. jugularis asianus and D. jugularis cypriacus.

All of these features in the population of Tilos are more widespread and emphasized, perhaps in relation to the more pronounced isolation conditions than those of the other conspecific neighboring populations (Fig. 2) (Cattaneo, 2009).

The holotype, an adult male specimen collected on Rhodes in the locality of "Laerma" on May 2015 , is currently part of the Herpetological Collection of the Alexander Koenig Museum in Bonn, Germany.

\section{References}

Bader T. \& Riegler C., 2004. Herpetologische Beobachtungen auf Rhodos (Griecheland). ÖGH-Aktuell, 13: 6-9.

Bader T., Riegler C. \& Grillitsch H., 2009. The Herpetofauna of the island of Rhodes (Dodecanese, Greece). Herpetozoa, 21: 147-169.

Bedriaga J. von, 1882. Die Amphibien und Reptilien Griechenlands. Bulletin de la Société impériale des naturalistes de Moscou, 56: 278-344. 
Boettger O., 1888. Verzeichniss der von Hrn E. von Oertzen aus Griechenland und aus Kleinasien mitgebrachten Batrachier und Reptilien. Sitzb. königl.preuß. Akad. Wiss. Berlin, 5: 139-186.

Calabresi E., 1923. Escursioni Zoologiche del Dott. E. Festa nell'Isola di Rodi. Bollettino dei musei di zoologia ed anatomia comparata della R. Università di Torino, 38: 1-16.

Cattaneo A., 2009. L'ofidiofauna delle isole egee di Halki e Tilos (Dodecaneso) con segnalazione di un nuovo fenotipo di Dolichophis jugularis (Linnaeus) (Reptilia Serpentes). Il Naturalista siciliano, 33: 131-147.

Cattaneo A., 2012. Il colubro gola rossa dell'arcipelago di Rodi: Dolichophis jugularis zinneri subsp. nova (Reptilia Serpentes). Il Naturalista siciliano, 36: 77-103.

Clark R., 1990. An appraisal of the status of Coluber jugularis and Elaphe quatuorlineata in Greece. Part 1. Herptile, Dudley, 15: 42-56.

Clark R., 1992. A collection of reptiles from the islands of Symi, Tilos and Gaidaronisi; Dodecanese, Greece. Herptile, Dudley, 17: 19-27.

Ščerbak N.N. \& Böhme W., 1993. Coluber caspius Gmelin, 1789 - Kaspische Pfeilnatter oder Springnatter. In: Böhme W. (Ed.), Handbuch der Reptilien und Amphibien Europas, Bd. 3/I, Schlangen (Serpentes) I. Aula-Verlag, Wiesbaden, pp. 83-96

Schlüter U., 2010. Die Herpetofauna von Symi. Elaphe. Rheinbach, 18: 62-67.

Wettstein O., 1953. Herpetologia aegaea. Denkschriften der Kaiserlichen Akademie der Wissenschaften / Mathematisch-Naturwissenschaftliche Classe, 162: 651-833.

Wilson M.J. \& Grillitsch H., 2009. The Herpetofauna of Simi (Dodecanese, Greece) (Amphibia, Reptilia). Herpetozoa, 22: 99-113.

Zinner H., 1972. Systematics and Evolution of the Species Group Coluber jugularis Linnaeus, 1758 Coluber caspius Gmelin, 1789 (Reptilia, Serpentes). Thesis, Jerusalem University. 